\title{
Determining porosity distribution in fractured basement rock of White Tiger oilfield by logging data
}

- Kha Nguyen Xuan

- Thanh Truong Quoc

- Huy Nguyen Xuan

- Xuan Tran Van

University of Technology, VNU-HCM- tvxuan@hcmut.edu.v

- Son Pham Xuan

- Quy Hoang Van

VSP Research \& Engineering Institute

(Manuscript Received on August 21 $1^{\text {th }}$, 2014; Manuscript Revised November 11 $1^{\text {th }}$, 2014)

\section{ABSTRACT:}

Commercial oil accumulation discovered in basement rocks of White Tiger oilfield opened a new exploration challenge for geologists and geophysics as well; simultaneously, it demonstrated the necessity to study this object more detail. $A$ lot of results concerning research in basement rocks and mechanism of pore space formation were presented in several conferences or/and published in professional journals. Almost problems were clarified by researchers; however,

for a comprehensive evaluation up to date the new data in which authors would like to focus on this paper, is determining the distribution of porosity in depth by logging data with supports of BASROC software version 3.0. When comparing the results of re-interpretation with additional new measurements with data summarizing 2006 show out that in basement rock the porosity decreases with depth; at zone $V$ the porosity decreases to the value much lower than previous research results.

Key words: logging methods, fractured basement reservoir, secondary porosity, fracture-vuggy porosity, BASROC software, oil-bearing basement reservoir.

\section{INTRODUCTION}

Since 1988 the oil has been begun produced from the White Tiger Pre-Cenozoic fractured basement reservoir. This oil reservoir being quite rare and atypical all over the world, with the oil- bearing thickness of nearly 2000 meters makes White Tiger oilfield become one of the biggest oil fields on the shelf of Vietnam. Up to January $1^{\text {st }}, 2008$ the cumulative oil production from this reservoir has reached to more than one billion barrels, contributed more than $90 \%$ of its total oil production [4].

The elevated White Tiger basement, located in the Central uplifted zone of Cuu Long basin, has the length and width of approximately $30 \mathrm{~km}$ and 6-8 km respectively and characterized by a tectonic destruction system of the main North East - South West orientation with three main rock complexes of Hon Khoai, Dinh Quan and Ankoret formed about 90 M.a to 240 M.a [1].

The whole elevated basement block was gradually sunk down at the beginning of Cenozoic period, and an especially important event happened at the end of Oligocene period. The White Tiger Central Block and other structures on the Central uplifted zone had been moved to the East by the West-Eastern horizontal tension, forming a number of uplift - reverse faults and densely distributed fractures system in the elevated basement. Along these uplift - reverse faults and 
fracture system, after being generated, developed mainly in the Central trough of basin, hydrocarbons migrated and accumulated in the elevated basement, pushing the whole enormous volume of water, which had been accumulated since millions of years ago, to the North and North-East flanks. Parts of this water immersed to the deep zones to take part in the secondary changing process. The reservoir initial pressure converted to the absolute depth of $-3650 \mathrm{~m}$ is $41.7 \mathrm{mPa}$. Based on tectonic point of view, the elevated basement is divided into the Central, Northern, North-Western, East-Western, Southern blocks and Eastern Depression [2]. The results of hydrodynamic investigations show that the whole reservoir is characterized by the united hydrodynamic system, especially in the Central Block. The remaining blocks have different circulation degrees. The whole elevated basement block is characterized by two intersectional fractures systems with the angles changing from $0^{0}$ to $90^{\circ}$, mainly from $50^{0}$ to $70^{\circ}$ [4]. From field study results there have been suggested a lot of reservoir models, but the most accepted is that one consists of macrofractures, microfractures and non-destructive rock zones (Fig. 1).

Macrofracture zones include parallel oriented big fractures formed by tectonic destruction, characterized by hydrodynamic permeability. Alongside of the fracture surfaces are densely distributed vug systems formed by the hydrothermal process taken place millions of years which contribute to the increase of basement rock permeability. Microfracture zones formed alongside of oriented big fracture surfaces enhances reservoir properties, communication among large fracture surfaces, characterized by capillary permeability. Solid non-destructive rocks have too low permeability and unfavorable reservoir properties [5].

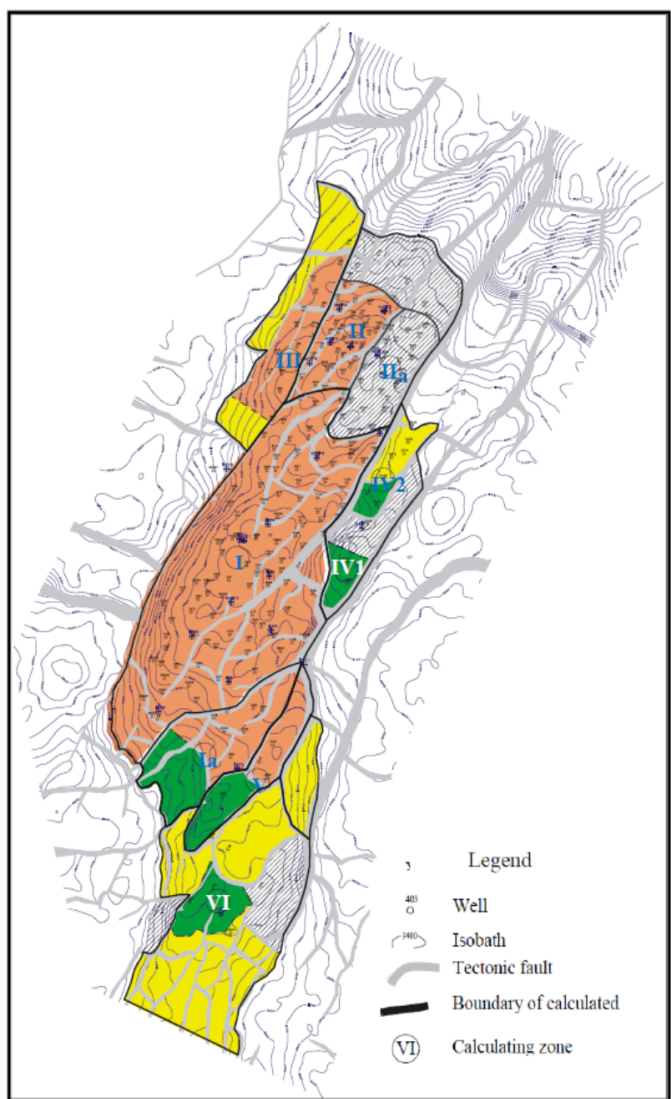

Fig. 1. Top structure map of White Tiger basement. (From Hoang Van Quy, 2008)

\section{METHODOLOGY}

Of the porous structure, the results of core analysis carried out by VSP Research \& Engineering Institute showed that there are apparently differentiated zones in the basement, which contain directional-oriented fractures characterized with high hydrodynamic conducting permeability. Besides the main directionaloriented macro fractures, there are also unidirectionaloriented micro fractures, which distributed along the surfaces of the macro fractures and characterized by capillary permeability (Fig. 2), [5]. The macro fractures are distributed irregularly with various distances from some meters to hundreds of meters.

\section{Trang 140}




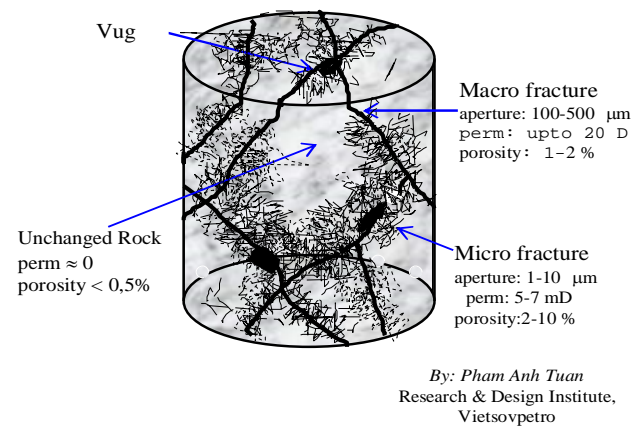

Fig. 2. Pore Space Structure of White Tiger basement reservoir. (From Hoang Van Quy et al., 2006)

\subsection{Determination of fractured-vuggy basement collector properties}

As concerned above, the hydrocarbon reservoirs in the fractured-vuggy basement are quite complicated in both lithology and porous structure matters. It is impossible to apply the conventional methods for determining of collector properties, as it is an incompatible model. Moreover, all well log data are applicable only in cases for an homogeneous environment and the relationship between the two physical measuring parameters and collector properties is consistent to the model of intergranular porosity. In order to improve the accuracy when determining the collector properties, it is necessary to consider a new approach in both of the study methodology and the choice of individual algorithms.

From the built physical-lithological model, the most important parameters to be applied for reservoir study and modeling of fractured basement rocks are derived as total porosity $\left(\Phi_{\mathrm{t}}\right)$, secondary porosity $\left(\Phi_{2}\right)$ and fractured porosity $\left(\Phi_{\mathrm{fr}}\right)[3]$.

\subsection{Determination of total porosity}

The lithologic content of fractured basement rocks are multi-mineral with variable ratio both in their volumes and components as well, hence determining the porosity by traditional and conventional methods would be highly prone to error due to the difficulty during evaluating the matrix rock parameters. In order to exclude the influence of multi-mineral factors which could have a significant effect on the physical measurement values reflected by logging responses, on $\log$ curves, the BASROC software version 3.0 applied a special algorithm to solve a series of multi-argument equations that consist of mineral (or group mineral) volumes and total porosity. This method utilizes the Error Minimization Technique to maximize the correlation coefficient between the theoretically synthetic curves and actual responses (Fig. 3).

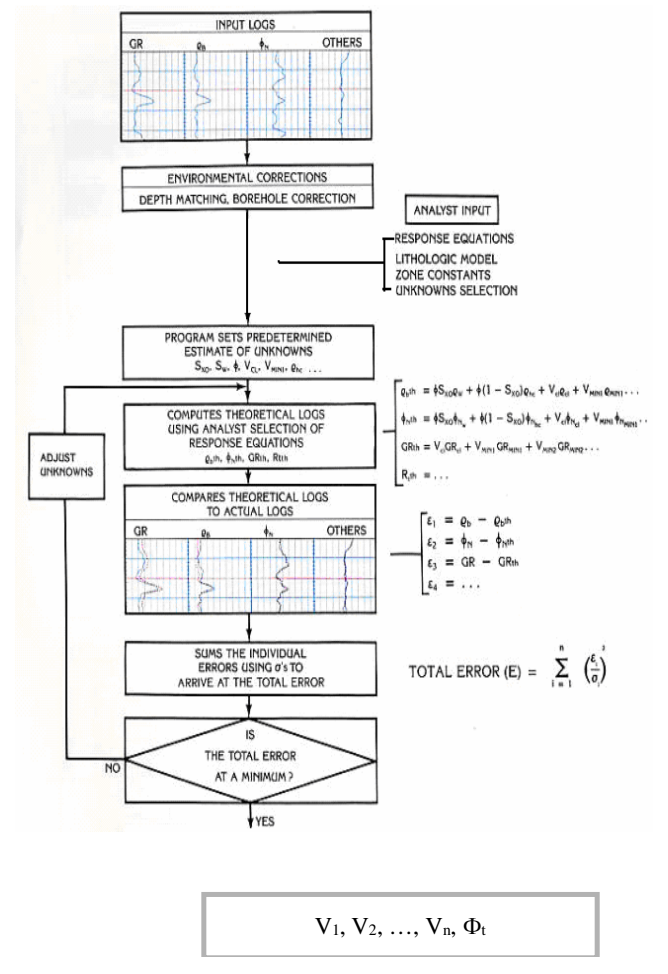

Fig.3. Flow-chart of total porosity determination (Hoang Van Quy 2008)

\subsection{Determination of secondary porosity}

The above-determined total porosity consists of primary intergranular porosity and fractured-vuggy porosity that formed in processes of tectonics, weathering, and magma contraction (that is induce secondary porosity). These open porosities combine differing types of porosity communicating together and containing fluids. The secondary porosity could be determined by below equation [3]: $\Phi_{2}=\frac{\phi-\phi_{\text {block }}}{1-\phi_{\text {block }}}$

Where: $\phi \quad$ - Total porosity;

$\phi_{0 \text { lock }} \quad$ - Porosity of tight rock, estimated in each basement zone. 


\subsection{Determination of fracture-vuggy porosity}

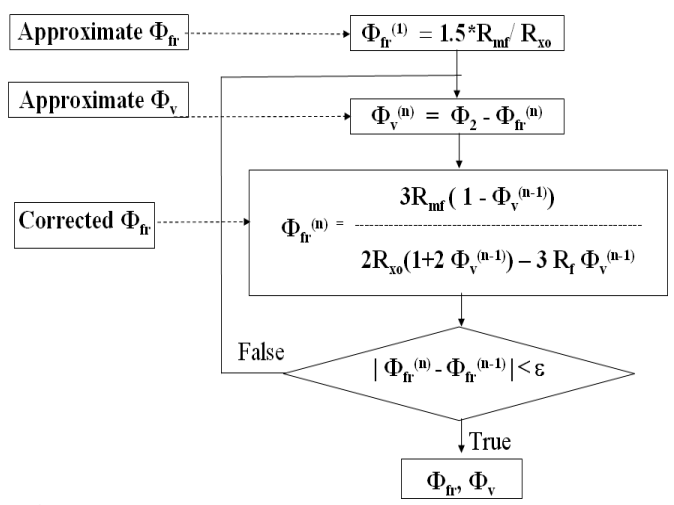

Fig. 4. Flow-chart of fracture-vuggy porosity determination (Hoang Van Quy 2006)

Fracture porosity $\phi_{\mathrm{f}}$ is estimated by Maxwell formula for fracture reservoirs and looping technique for exclusion of the influence of vugs that could be significantly affected by resistivity values of invaded zones (Rxo) which are reflected by logging responses. This algorithm may be created with the following flowchart (Fig. 4) [3]:

\subsection{The result evaluation}

Based on reinterpretation wellogging data from 163 wells which fully implemented the combination of quality measurement and well documented in the basement (with new data updated since 2006) to permit enhanced the reliable of results during determine the matrix parameters and mineral content as well. Compared with results interpretation 2006, in 2011 both BASROC versions 2.0 and 3.0 are applied for data interpretation. There are advantages of version 3.0 compared to version 2.0 by adding correction function for the effect on the lithological composition curve during determine the porosity by wellog method. Since fractured basement rocks have complex lithological composition, each lithological component accounting for different parts of the rock volume, therefore, the routine method of determining the porosity usually make serious error due to the difficulty when determining the parameters of the rock matrix. To eliminate the role of mineral elements, the most significantly factors affect the outcome and interpretation wellog data results, the BASROC version 3.0 applied the specialized algorithms in other to solve multi-variable equations to calculate the concentration of minerals (or mineral composition).

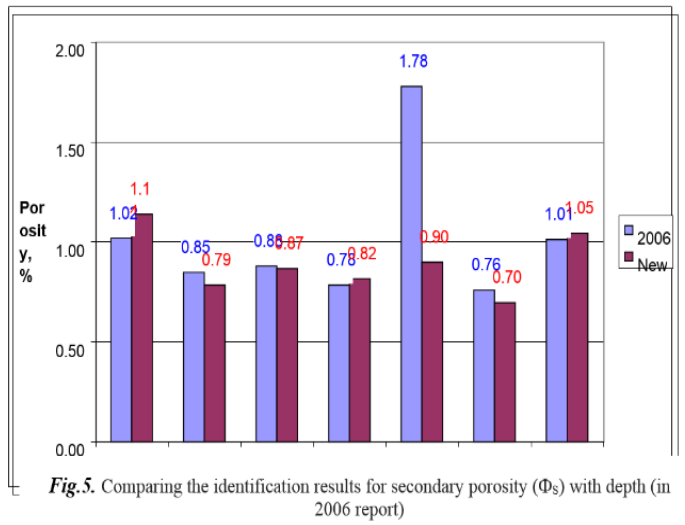

The comparisons of the average value of secondary porosity ( $\Phi \mathrm{s})$ in overall fractured basement formation with former results (in 2006) are shown in figure 5 and table 1. According to the comparison result, the value of secondary porosity $\Phi$ s used in calculating this reservoir may increase not much more than the value reported in 2006, particularly $\Phi$ s increased $0.04 \%$.

Table 1: Porosity in basement rocks of White Tiger structure

\begin{tabular}{|c|c|c|c|}
\hline \multirow{2}{*}{ Zone } & \multicolumn{2}{|c|}{$\left(\Phi_{s}\right), \%$} & \multirow{2}{*}{$\begin{array}{c}\text { Error range } \\
(\%)\end{array}$} \\
\hline & 2006 & New data & \\
\hline$I \&$ Ia & 1.02 & 1.14 & 0.12 \\
\hline п & 0.85 & 0.79 & -0.06 \\
\hline III & 0.88 & 0.87 & -0.01 \\
\hline $\operatorname{IV}(1,2)$ & 0.78 & 0.82 & 0.04 \\
\hline $\mathrm{v}$ & 1.78 & 0.90 & -0.88 \\
\hline VI & 0.76 & 0.70 & -0.06 \\
\hline Total & 1.01 & 1.05 & 0.04 \\
\hline
\end{tabular}

The significant reduction range of secondary porosity in the zone $\mathrm{V}$ can be explained by secondary porosity identified in previous reports quite high: the average value of the properties $\Phi$ s zone V $(\Phi s=1.78 \%)$ is much higher than the calculated value at zone $\mathrm{I}(\Phi \mathrm{s}=$ $1.02 \%$ ) - where the basement rock has been shown to strongest break level, is unreasonable, (Figure 6). The average value of $\Phi \mathrm{s}$ in the zone $\mathrm{V}$ dropped to $0.9 \%$ as a result of interpretation by BASROC version 3.0, this suggests that there is a higher match with the general background of the new $\Phi$ s due to the change of secondary porosity in the oil-bearing basement reservoir (Figure 7).

\section{Trang 142}



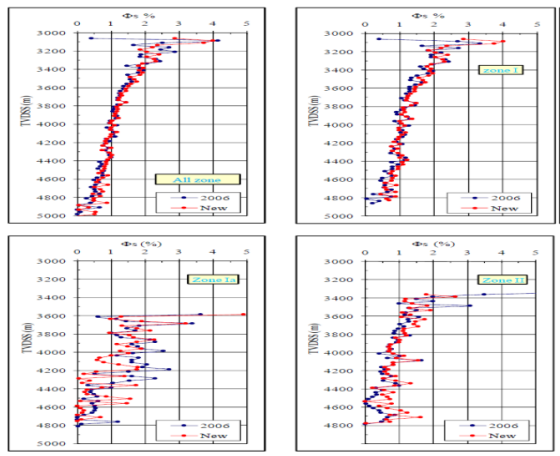

Fig.6. Comparing the identification results for secondary porosity $\left(\Phi_{\mathrm{S}}\right)$ with depth (in 2006 report)
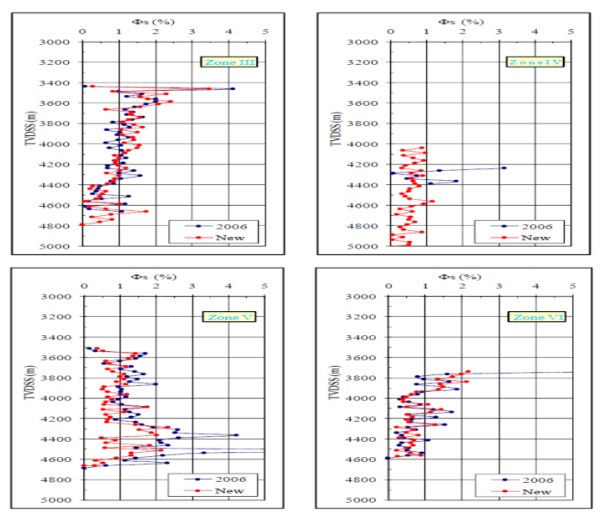

Fig.7. Comparing the identification results for secondary porosity $\left(\Phi_{\mathrm{S}}\right)$ with depth (in 2006 report)

\section{CONCLUSION}

The fracture-vuggy basement reservoirs in White Tiger oil field have unique and complex geological structure, which are characterized by highly heterogeneous mineral distribution and porous structures in which formed in basement rocks. In order to improve the accuracy during determining porosity $\Phi \mathrm{s}$ of reservoir parameters, the BASROC 3.0 with several advantages are applied, the research results are numerated there after:

- The secondary porosity decreases with depth.

- New results of $\Phi$ s are increasing of $0.04 \%$ higher than previous value, (2006).

- The significant reduction of secondary porosity in the zone $\mathrm{V}$ due to secondary porosity identified in previous reports quite high: the average value of the properties $\Phi$ s zone V ( $\left.\Phi_{\mathrm{s}}=1.78 \%\right)$ is much higher than the calculated value at zone I $(\Phi s=1.02 \%)$.

The average value of $\Phi$ s in the zone V dropped to $0.9 \%$ as a result of interpretation by BASROC version 3.0, due to the change of secondary porosity in the oilbearing basement reservoir. 


\section{Xác định phân bố độ rỗng trong đá móng nứt nẻ mỏ Bạch Hổ bằng tài liệu địa vật lý giếng khoan}

- Nguyễn Xuân Khá

- Trương Quốc Thanh

- Nguyễn Xuân Huy

- Trần Văn Xuân

Trường Đại học Bách khoa, ĐHQG-HCM- tvxuan@hcmut.edu.vn

- Phạm Xuân Sơn

- Hoàng Văn Quý

Viện nghiên cứu và thiết kế dầu khí biển, Liên doanh dầu khí Việt Nga

\section{TÓM TÁT:}

Tích tụ dầu khí thương mại được phát hiện trong đá móng mỏ Bạch Hổ mở ra một thách thức mới cho thăm dò địa chất và địa vật lý; đồng thời cũng chứng minh sự cần thiết phải nghiên cứu chi tiết các đối tượng này hơn. Rất nhiều kết quả liên quan đến nghiên cứu trong đá móng và cơ chế hình thành không gian rỗng đã được trình bày trong một số hội nghị và / hoặc công bố trên các tạp chí chuyên nghiệp. Hầu hết các vấn đề đã được đề cập, quan tâm bởi các nhà nghiên cứu; Tuy nhiên, để đánh giá một cách toàn diện về phân bố độ rỗng trong đá móng cần có bộ dữ liệu đủ lớn và liên tục cập nhật, trong phạm vi bài báo, tác giả tập trung vào xác định sự phân bố của độ rỗng từ số liệu địa vật lý giếng khoan với sự hỗ trợ của phần mềm BASROC phiên bản 3.0. Khi so sánh các kết quả của tái minh giải với các phép đo mới bổ sung với dữ liệu đã tổng kết năm 2006 cho thấy trong đá móng nứt nẻ mỏ Bạch Hổ độ rỗng giảm dần theo theo chiều sâu; tại khu vực $V$ độ rỗng có giá trị thấp hơn nhiều so với kết quả nghiên cứu năm 2006.

Từ khóa: Phương địa vật lý giếng khoan, đá móng nứt nẻ, độ rỗng thứ sinh, đứt gãy -hang hốc, độ rỗng, phần mềm BASROC, thân dầu trong đá móng.

\section{REFERENCES}

[1]. Tran Le Dong, Kiriev F.A. The igneous rocks in White Tiger basement and characteristics of reservoir rocks formation. Collection of papers of the conference " $15^{\text {th }}$ Vietsovpetro Anniversary 1981/1996”. Hanoi, 1997.

[2]. Vu Nhu Hung, Trinh Van Long, Pham Tat Dac, Pham Dinh Hien, Hoang Thi Xuan Huong, Tran The Hung, Dinh Thi Anh. Petrology of basement granitoid in White Tiger and Dragon oil fields and adjacent area within Cuu long basin. International conference "Fractured basement reservoir" Vung Tau, 2008.

[3]. Hoang Van Quy, Pham Xuan Son, and Dang Duc Nhan. BASROC 3.0: special software for processing wireline logs in fractured basement. International conference "Fractured basement reservoir" Vung Tau, 2006.

[4]. Hoang Van Quy, Oil reservoir in the basement of white tiger oil field and solutions to the regulation of the production regime for enhancing oil

\section{Trang 144}


recovery. International conference "Fractured basement reservoir” Vung Tau, 2008.

[5]. Hoang Van Quy, Phạm Xuan Son, Tran Xuan Nhuan and Tran Duc Lan, Reservoir parameter evaluation for reservoir study and modelling of fractured basement White Tiger oil field. International conference "Fractured basement reservoir" Vung Tau, 2008. 